\title{
Farewell to Professor David Yaffe - A pillar of the myogenesis field
}

Zipora Yablonka-Reuveni (1), Frank Stockdale (2), Uri Nudel (3), David Israeli (4), Helen M. Blau (5), Asher Shainberg (6), Sara Neuman (7), Gania Kessler-Icekson (8), Erica Meghid Krull (9), Bruce Paterson (10), Ora Saxel Fuchs (11), David Greenberg (12), Rachel Sarig (3), Orna Halevy (13), Eijiro Ozawa (14), Don J. Katcoff (6)

(1) Department of Biological Structure, University of Washington School of Medicine, Seattle, WA, USA; (2) Stanford University School of Medicine, CA, USA; (3) Department of Molecular Cell Biology, Weizmann Institute of Science, Rehovot, Israel; (4) Genethon, INSERM U-951, Evry, France; (5) Stanford University School of Medicine, Institute for Stem Cell Biology and Regenerative Medicine, Department of Microbiology and Immunology, Clinical Sciences Research Center, Stanford, CA, USA; (6) The Mina \& Everard Goodman Faculty of Life Sciences, Bar-Ilan University, Ramat-Gan, Israel; (7) Ness-Ziona, Israel; (8) Laboratory of Cellular and Molecular Cardiology, Felsenstein Medical Research Center, Rabin Medical Center, Petah-Tikva, and Sackler Faculty of Medicine, Tel-Aviv University, Tel-Aviv, Israel; (9) Easton, Massachusetts, USA; (10) Laboratory of Biochemistry and Molecular Biology, National Institutes of Health, Bethesda, Maryland, USA; (11) Rehovot, Israel; (12) Department of Biological Chemistry, The Alexander Silberman Institute of Life Sciences, The Hebrew University of Jerusalem, Jerusalem, Israel; (13) Faculty of Agriculture, The Hebrew University, Rehovot, Israel; (14) National Institute of Neuroscience, NCNP, Tokyo, Japan.

This article is distributed under the terms of the Creative Commons Attribution Noncommercial License (CC BY-NC 4.0) which permits any noncommercial use, distribution, and reproduction in any medium, provided the original author(s) and source are credited.

\begin{abstract}
It is with great sadness that we have learned about the passing of Professor David Yaffe (19292020, Israel). Yehi Zichro Baruch - May his memory be a blessing. David was a man of family, science and nature. A native of Israel, David grew up in the historic years that preceded the birth of the State of Israel. He was a member of the group that established Kibbutz Revivim in the Negev desert, and in 1948 participated in Israel's War of Independence. David and Ruth eventually joined Kibbutz Givat Brenner by Rehovot, permitting David to be both a kibbutz member and a life-long researcher at the Weizmann Institute of Science, where David received his $\mathrm{PhD}$ in 1959. David returned to the Institute after his postdoc at Stanford. Here, after several years of researching a number of tissues as models for studying the process of differentiation, David entered the myogenesis field and stayed with it to his last day. With his dedication to the field of myogenesis and his commitment to furthering the understanding of the People and the Land of Israel throughout the international scientific community, David organized the first ever myogenesis meeting that took place in Shoresh, Israel in 1975. This was followed by the 1980 myogenesis meeting at the same place and many more outstanding meetings, all of which brought together myogenesis, nature and scenery. Herein, through the preparation and publication of this current manuscript, we are meeting once again at a "David Yaffe myogenesis meeting". Some of us have been members of the Yaffe lab, some of us have known David as his national and international colleagues in the myology field. One of our contributors has also known (and communicates here) about David Yaffe's earlier years as a kibbutznick in the Negev. Our collective reflections are a tribute to Professor David Yaffe. We are fortunate that the European Journal of Translational Myology has provided us with tremendous input and a platform for holding this 2020 distance meeting "Farwell to Professor David Yaffe - A Pillar of the Myogenesis Field".
\end{abstract}

Key Words: myogenesis, myology, muscle, myoblasts, Professor David Yaffe, L6, L8, C2, Kibbutz Revivim, Kibbutz Givat Brenner, Weizmann Institute of Science. 


\section{The way I remember David Yaffe}

\section{by Zipora Yablonka-Reuveni, PhD}

Professor, Biological Structure, University of Washington School of Medicine, Seattle, Washington, USA. E-mail: reuveni@u.washington.edu

Dear Friends and Colleagues,

It is with great sadness that I write to inform you of the passing of Professor David Yaffe. The funeral was on Sunday, July 5, 2020 at his kibbutz, Givat Brenner, Israel. Yehi Zichro Baruch - May his memory be a blessing. David is survived by his wife of many years, Ruth, his daughter, two sons, many grandchildren and their families - we send them our condolences.

David has left behind two gigantic legacies, his family and the field of myogenesis of which he was one of the founding members and to which he has contributed continuously even in most recent years. ${ }^{1-98}$

David was born and raised in Tel-Aviv. ${ }^{99}$ As a young man in the formative years of pre-state Israel, David volunteered to the Palmach (an elite fighting force) and in 1948 he participated in Israel's Independence War as a communication expert that included operating homing pigeons. David started his studies at the Hebrew University of Jerusalem in 1952 and after completing his MSc in biology he pursued his $\mathrm{PhD}$ studies at the Weizmann Institute of Science with Professor Michael Feldman, graduating in 1959. Following his postdoctoral research at Stanford University, David returned to the Weizmann Institute and started his independent research in 1961. The cancer research he had carried out at Stanford suggested to David that cancer could be understood as a pathological form of growth and development, and his research therefore turned to development. David began experimenting with various types of tissues, until he finally settled on muscle cells as useful models of development. ${ }^{11,12}$

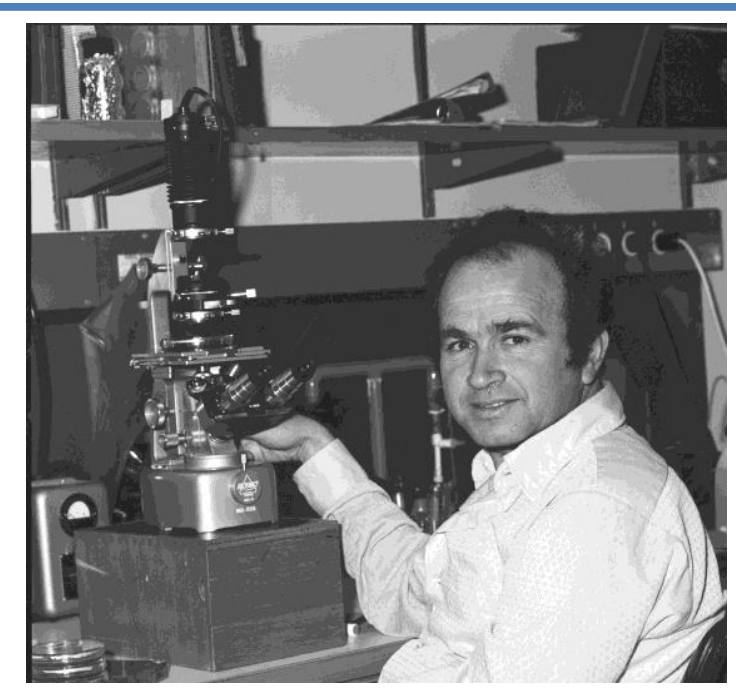

Fig 1. David Yaffe, early 1970's. (Photo credit Weizmann Institue of Science).
David's pioneering studies established in vitro models to analyze rodent myogenesis ${ }^{11,12,16-18}$ and contributed to our research community the most valuable and widely available myogenic cell lines. ${ }^{19,22,29,30}$ Along with many years of researching cellular and molecular aspects of developmental myogenesis, ${ }^{16-57}$ David applied his lab discoveries to the cellular management of Duchenne Muscular Dystrophy ${ }^{26,58,59}$ and neurological disorders. ${ }^{67-}$ 76,88,91-98 David's contributions have inspired, and will continue to enhance, the broader field of "regenerative myology". 100,101

David's appreciation of nature extended far and beyond lab research. His love of nature is a vivid aspect of his personality that I have carried with me since the first day I met him in the summer of 1973, when he agreed to accept me as a graduate student. Just like biological research in the lab, our surroundings offer so much, even to the naked eye. We just need to look around and discover their beauty as it is there, waiting — no need to take far away trips to other continents, just look around, and see the flowers, the trees, the views, the history, and preserve it as the best as you can. Some of you may remember the myogenesis meetings David organized in Israel, starting with the first ever myogenesis meeting (1975) at Shoresh. ${ }^{102}$ At these meetings, in addition to the amazing scientific program, David always included sightseeing trips - to see nature, archaeological sites, history, humanity.

I was a member of David's lab during the years 19731976. I started my research by investigating the potential of Xenopus oocytes to serve as a translational machinery to analyze differentiation-associated gene expression as directed by injected mRNA / polyribosomes isolated from rat myogenic cultures. Apart from huge tub of water in which the female Xenopus frogs were swimming, I had to invent all the other tools required to make the system work. I also had to provide the nourishment to the frogs, and went now and then to the local butcher to purchase bovine liver to feed the swimmers. Using the Xenopus oocyte system, I was able to demonstrate an efficient translation of control RNA (globin), but the hope of translating the high molecular weight $(200 \mathrm{kDa})$ sarcomeric myosin heavy chain was not fulfilled. I then moved to a somewhat easier system to work with, the wheat germ cell free translation system, which enabled me to discover and further study, myogenic-specific gene expression of sarcomeric myosin light chains ( $\mathrm{Z}$. Yablonka and D. Yaffe). ${ }^{28,32} \mathrm{I}$ was fortunate to have the support and input of wonderful team members. In particular acknowledgements are due to Gania KesslerIcekson and Bruce Paterson who were already well into their doctoral and postdoctoral studies, respectively, when I joined the lab.

Yaffe's group at that time was composed of a vibrant group of students, postdocs and technicians. Our research was focused on transcriptional, post-transcriptional and translational controls of myogenesis, using the most advanced methodology of that time. We worked hard 


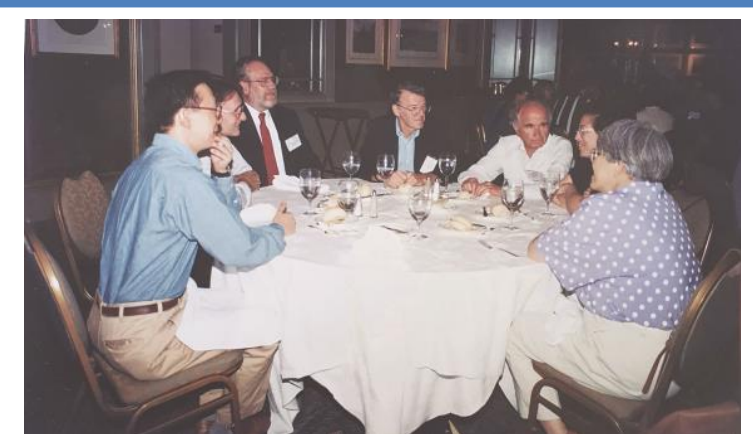

Fig 2. The first satellite cell meeting, Boston, 1998. From left, Drs. Ryuichi Tatsumi, Ron Allen, Richard Bischoff, Bruce Carlson, David Yaffe, Zipora Yablonka-Reuveni, Oicheng $\mathrm{Ng}$.

(Photo credit Dr. Judy Anderson; found and contributed by Dr. Orna Halevy).

with plenty of room for independent research and creativity. Some of the "ground rules" were difficult for the young spirit, but ended up serving as good lessons for years to come. Important findings were not merely dependent on picking a statistical test, but had to be very clear and obvious and reproducible numerous times. Results with cell lines were never good enough and had to be researched further with primary cells before any publication could be considered. Manuscripts often needed to be left in a drawer for a year and then be revisited to see if the report was still of interest and value.

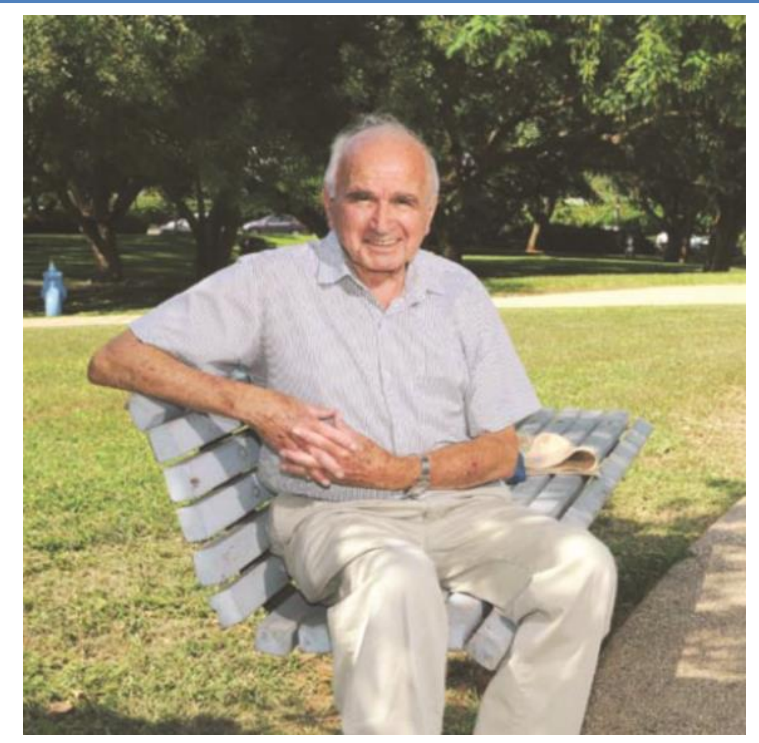

Fig 3. David Yaffe, circa 2008.

(From https://wis-wander.weizmann.ac.il/books/graduates). ${ }^{99}$
Indeed, there were days when we came out of David's office storming and even crying, ready to never come back again, yet, the next day, the sun was shining again and we were ready to continue. I admit, without any reservations, that the years at David's lab were the best years of my scientific creativity, enabling me to focus solely on the research, with nothing else in the way.

David was not just a mentor to lead students to the next level. He knew us and our families, he approved (or disapproved) of our boyfriends/girlfriends, he attended our weddings, he complimented us, and at times, made us angry, but we survived and continued and have stayed in touch with him and never thought the day would come when he would no longer be here (just as children think of their parents). For me in particular, our last names certainly have kept us together for many years. Whether it was by the Hebrew or English alphabet, we were always listed next to each other at gatherings and scientific meetings, "Yablonka" and "Yaffe" - I was delighted with this "linked" status.

I left David's lab forty five years ago, yet lost my mentor just now - on the personal level, one more touchstone of my "childhood" is gone.

\section{Acknowledgments}

David left this world at the age of 91, bequeathing us an everlasting wealth of scientific knowledge and tools. Certainly, this publication of reflections and nostalgia is not aimed at detailing David's numerous scientific accomplishments, but it is dedicated to the messages I have received (or at times solicited for this distance meeting) after announcing that David passed away. I thank each of the coauthors of this publication for sharing their reflections as included below.

I am additionally grateful for the kind words that many other colleagues have sent me. These include: Ronald Allen, University of Arizona; Judy Anderson, University of Manitoba; Jeffrey Chamberlain, University of Washington; Emanuela Gussoni, Boston Children's Hospital; Miranda Grounds, University of Western Australia; Rebecca Hartley, University of New Mexico; Gabrielle Kardon, University of Utah; Leslie Leinwand, University of Colorado Boulder; Ryoichi Matsuda, Tokyo University of Science; Jennifer Morgan, University College London; Terence Partridge, George Washington University; Michael Phelps, Washington State University; Michael Rudnicki, University of Ottawa \& Ottawa Hospital Research Institute; Stanley Salmons, University of Liverpool; Robert Singer, Albert Einstein College of Medicine; Matthew Taylor, University of Sydney.

Our "global community" is saying farewell to David.

Zipora Yablonka-Reuveni 


\section{Roots}

\section{by Frank E. Stockdale, MD, PhD}

Maureen Lyles D'Ambrogio Professor of Medicine, Emeritus, Stanford University, California, USA. E-mail: stockdale@stanford.edu

In Hebrew the word for "root" of something is Shoresh. David Yaffe was among those who are at the root of our field of myogenesis.

While Schwann first noted in 1839 that muscle tissue contained cells with many nuclei, it was a century before techniques provided avenues to determine why. During that time tissue culture (Harrison) and then cell culture (Rous, Zwilling, Moscona) and then cloning (Puck) of individual cells appeared. Remember, the field of developmental biology was emerging in the 1950s. The Journal of Developmental Biology first appeared in 1959, we were all "embryologists" prior to that. The modifications and application of cell culture opened investigations into myogenesis, which came into its own in the early 1960s in a small number of laboratories. During this time David perfected and expanded on the work of early investigators, first with the rat muscle cell lines ( $\mathrm{L}$ lines), and then a decade later the mouse cells lines (C2) establishing the important basic principle that cells and cell lines could be produced that perpetually manifest specific differentiated products and morphological features as well as providing a tool that subsequently was used by hundreds of investigators to expand our understanding of basic mechanism of cell differentiation and myogenesis.

David's work along with others (Kongisberg, Holtzer, Mauro) and their students in the early 1960's established myogenesis as among the important research areas which subsequently have influenced the general understanding of cell differentiation. Today there are hundreds of distinguished investigators, too many of you to acknowledge, whose work is rooted in the work of those who went before. Because of David, the early meetings at Shoresh and elsewhere established Israel, as a central facilitator for transfer of information, collaboration, and the social-scientific structure so important for our field. David tirelessly fostered these and the conferences that subsequently took place around the world. We are indebted to David for this, because without his efforts all of us would have had a harder time developing our careers.

Sadly, we have lost Konigsberg, Holtzer, and now David. David's career stands as an example that we all can try to emulate. He tenaciously pursued a research goal, encouraged others, facilitated communication, and remained curious and scientifically engaged throughout his life.

I miss his presence.

Frank E. Stockdale
Eulogy - read in Hebrew at David Yaffe's funeral, Kibbutz Givat Brenner, July 5, 2020

\section{by Uri Nudel, PhD}

Professor, Department of Molecular Cell Biology, Weizmann Institute of Science, Rehovot, Israel.

E-mail: uri.nudel@weizmann.ac.il

I worked with David for about 30 years during which time I greatly admired and valued him both as a scientist and as a person.

Here I write about him as a scientist - David was highly respected internationally and was sought after by visitors to the Weizmann Institute.

As a scientist, David had original and innovative ideas that served as a basis for his research during his long career. The biological system that he developed, and which served as the basis for his work, was to culture mononucleated cells that he could induce to fuse and differentiate into muscle fibers. To accomplish this, he first isolated myoblasts from animals and learned to culture them such that they would multiply in culture. He discovered that he could change the media conditions such that the cells would fuse into muscle fibers. This system served as the basis for David's research in studying the mechanism of cell fusion and the formation of the myotubes. This was followed by establishing myogenic cells lines. One of the cell lines that David founded 43 years ago together with Ora Saxel Fuchs, is named C2. This cell line continues to serve as the basis for many research projects around the world, having served as a model system in more than 2000 publications to date.

During the 70's and 80's of the previous century, David organized a number of international conferences on myogenesis in Israel. Those conferences were so successful that the participants decided to organize similar conferences in Europe.

In recent years we worked together on the gene that, when mutated, causes Duchene Muscular Dystrophy. Among other discoveries, we found that the gene is expressed not only in muscle, but also in brain. This helped explain the reduced IQ in a subset of the Duchene patients. Another important finding was our identification of a small segment of the gene that is independently expressed in the brain. Other groups found that when that portion is absent IQ is lowered further.

I am sure that David will be remembered for his scientific work as well as for the $\mathrm{C} 2$ cell line that he established, which continues to be the basis for tens of studies a year around the world.

Yhei Zichro Baruch - May his memory be a blessing.

Uri Nudel 


\section{In memory of David Yaffe: kibbutznik, naturalist and scientist}

\section{by David Israeli, PhD}

Research Scientist, Progressive Muscular Dystrophy Unit, Genethon, INSERM U-951, Evry, France.

E-mail: Israeli@genethon.fr

I first met David in 1994 when I came to study for my $\mathrm{PhD}$ at the Molecular Cell Biology Department of the Weizmann Institute. My father told me that I might meet an old-time friend of his, David, and indeed, I found that the laboratory of David Yaffe and Uri Nudel was located nearby in the same building. At the first opportunity, I presented myself and asked David if he would like to go for lunch at the nearby restaurant. David answered that it shall be with pleasure, but not at a restaurant since he has a fixed lunch meeting every day, and he invited me to join him. To my question where and with whom, he answered that it will be outside on a vast lawn in front of the laboratory building, and that I shall see the rest. Shortly after we met outside on the lawn with our lunch boxes, sitting down directly on the grass (David was almost 70 years old), when suddenly the third participant showed up. It was a young grey raven that landed 2 meters from us, jumping nervously, hesitating. David told me that he is afraid of me, as I was a stranger. It appeared that David and the raven were friends already for some time, sharing David's lunch box every day. Indeed, soon the bird approached for his daily pick, grabbing directly from David's hands, ignoring my interference.

At the same occasion David told me about his period with my parents. This went many years back to 1949-52 at

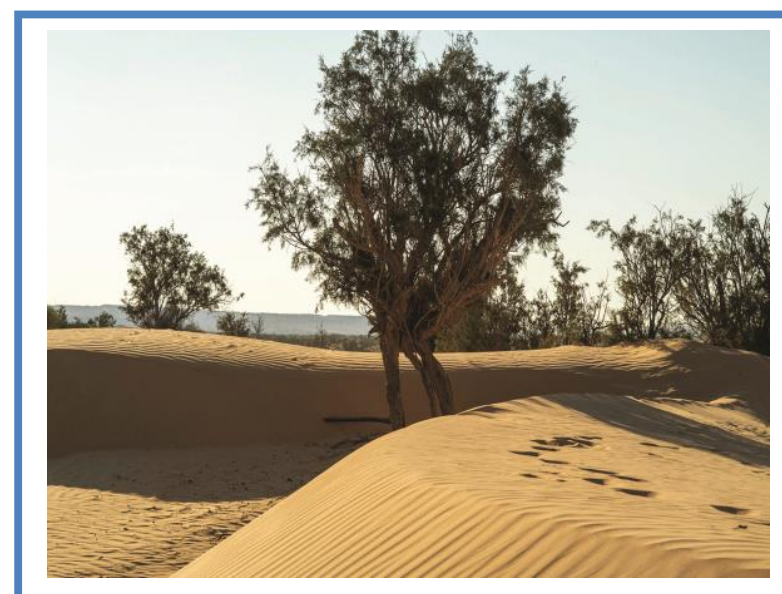

Fig 4. Tamarix aphylla plantation, Negev, Israel.

As a member of Revivim (1949-1952), David Yaffe participated in planting Tamarix aphylla to fight the sand storms in the Negev desert by Kibbutz Revivim.

(Photo credit Ezra Tzahor, Revivim, Israel)

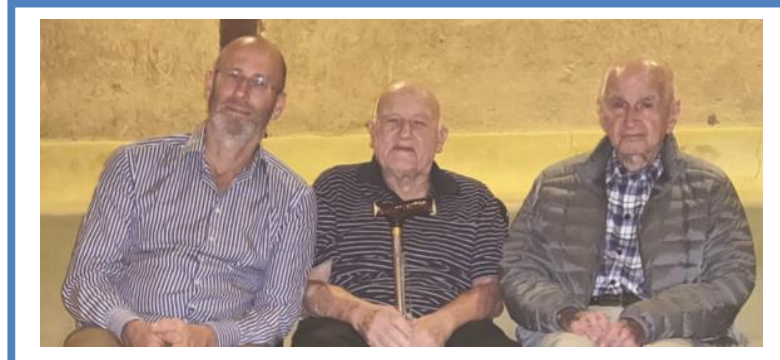

Fig 5. David Yaffe on the right, Eli Israeli (my father), in the middle, and myself on the left, November 2019.

(Photo credit Dr. David Israeli)

Kibbutz Revivim in the Israeli Negev desert. David, his wife Ruthy, and my parents were among the pioneers in this remote desert point in the south of Israel.

The settlement was surrounded by sand dunes that transformed often during windy conditions into heavy dust storms, penetrating everywhere and covering everything. The kibbutz people decided to fight the sand storm by planting trees. David told me that he participated in a mission of planting thousands of trees (Tamarix aphylla), capable of surviving without irrigation in the arid conditions, to slow down the drifting sand and flying dust. I knew the place very well, a large planted area, $5 \mathrm{~km}$ west of the kibbutz, where years later I used to play with my friends. These heroic years in Revivim were our best, he told me. "Why did you leave?" I asked. He answered that he could not reconcile his personal ambition of a scientific career with the demanding lifestyle of Revivim, at that time.

In another episode, at the end of my $\mathrm{PhD}$, knowing that $\mathrm{I}$ am going to join a muscle group, I asked David if he had particular advice and reagents that I might take with me. He took me to a small ancient liquid nitrogen container and handed me a tube of $\mathrm{C} 2$ cells, original $\mathrm{P} 7$, stored for over 25 years. This way, he told me, you need not order the $\mathrm{C} 2 \mathrm{C} 12$ from the ATCC. "Take the originals," he said, "as they differentiate much better!"

In November 2019, I visited my parents. By coincidence, the four generations of the Yaffe family gathered the same weekend in Revivim, where David and Ruthy originally met, for Ruthy's 90th birthday celebration. David and Ruthy invited their old-time kibbutz mates to talk with the Yaffe family. I accompanied my parents to reach the meeting place, and was very happy for the occasion to see David again and for the first time, Ruthy too.

I could not know that it was to be my last meeting with David.

David Israeli 


\section{My reflections on David}

\section{by Helen M. Blau, PhD}

Donald E. and Delia B. Baxter Foundation Professor, Director, Baxter Laboratory for Stem Cell Biology, Stanford University School of Medicine, Institute for Stem Cell Biology and Regenerative Medicine, Department of Microbiology and Immunology, Stanford, CA, USA. E-mail: hblau@ @stanford.edu

David Yaffe came to Stanford to spend a sabbatical with Robert Schimke in 1979, when I was a new assistant professor. He visited almost daily to look at our muscle cells and advise us on their culture and analysis, demonstrating tremendous energy and unwavering enthusiasm. He was extremely persuasive, determined and impactful. He managed to completely charm me and my highly capable lab assistant, Cecelia Webster, borrowed my bicycle for the duration of his stay, had my secretary type many a letter and paper, and offered Cecelia a job. During that period we obtained our first biopsies from Duchenne Muscular Dystrophy patients and David's tips on primary myogenic cultures were invaluable. Amusing, insightful, and helpful, I was extremely lucky that David took so much interest in my lab at that time.

David pioneered the development and use of long-lasting rat myogenic cell lines, L6 and L8, and brought the mouse C2 line to my lab while at Stanford. At that time, I was interested in testing whether the differentiated state was fixed and irreversible, the dogma at that time, or if it could be changed. I reasoned that the increased gene dosage afforded by multinucleate syncytial muscle cells was ideal for testing that idea. However, we struggled to do these experiments using primary muscle cells. David's C2 line made our experiments possible. Using mouse $\mathrm{C} 2$ cells we created heterokaryons, fusion products of mouse myotubes and human keratinocytes, fibroblasts, or hepatocytes. This system revealed that human cells that were specialized for completely different functions could be induced to activate and express previously silent myogenic genes that they would not normally express. Through these experiments we demonstrated the plasticity of the differentiated state. I wanted to make the $\mathrm{C} 2$ cells, which I viewed as a tremendous resource, available to the community at large. David, although initially reluctant, was eventually extremely pleased and proud that his cells were made available through the ATCC, as they profoundly impacted the field. The $\mathrm{C} 2$ cell line, which has enabled countless experiments, is now a major part of David's legacy.

David gave me my first big opportunity to give a talk at an international muscle meeting he organized in Shoresh, Israel in 1980. This meeting was unforgettable. During the meeting we hiked the Wadi Qelt from Jerusalem to Jericho in spring, amidst a glorious abundance of wild flowers in full bloom, a miracle of beauty and inspiration that regrettably can no longer be accessed. In addition, due to David, there were four women speakers on the program, which was revolutionary at the time. One was Margaret Buckingham with whom I have been friends ever since. That meeting made a deep impression on me - and launched me in the field. For that I am forever grateful.

David faithfully attended the muscle meetings and continued to be a strong voice well into his 80 s. I gave him an award at the GRC meeting in Il Ciocco in 2017. He looked quizzical, skeptical and reticent when I asked him to come to the podium. Then he broke into a huge smile when I announced that we wanted to honor him for his pioneering contributions to myogenesis. He was radiant with happiness and truly surprised. It was a magical moment I'll always remember, the more so since it was my last opportunity to be with him.

I miss him. David was a force of nature - and muscle.

Helen M. Blau

$$
* * * * *
$$

\section{A pioneer in David's lab}

\section{by Asher Shainberg, PhD}

Professor Emeritus, The Mina \& Everard Goodman Faculty of Life Sciences, Bar-Ilan University, RamatGan, Israel. E-mail: asher.shainberg@ gmail.com

I first met Prof. David Yaffe in 1964 while looking for a position as a student for Master's degree. I was privileged to be David's student at the Weizmann Institute, a period that later marked my scientific path. My thesis, which I performed in David's lab, was on electrical activity of skeletal and cardiac muscle grown in cell culture. The question that I tried to solve was if cardiomyoblasts that entering the myotube, will change the electrical properties, such as action potentials, of the skeletal muscle? The lab was not equipped with electrophysiological equipment. There was no oscilloscope, no electrode puller, no micromanipulator to enter the cells with microelectrode and therefore I had to start from scratch. I got a micromanipulator from another lab and an oscilloscope I created from Heat Kit parts. When I finished the master thesis and started my PhD studies (as the first doctoral student supervised by David) I changed the subject to fit the work running in the lab: differentiation of skeletal muscle. We showed, for the first time, that fusion of myoblasts to produce myotubes, depends on $\mathrm{Ca}^{2+}$ (Published in Experimental Cell Research 58; 163-167, 1969). ${ }^{21}$ We continued with analysis of enzymatic activities during muscle differentiations (Published in Developmental Biology 25;1-29, 1971). ${ }^{23}$ These 6 years that I spent in David's lab were very important to my future scientific and academic career. We used to, almost every day, eat lunch together in a Yemenite restaurant and discuss various topics, not only related to science. Since then we were in touch from 
time to time. When I retired, David came to the party organized by my Faculty at Bar-Ilan University and a short film, in which he gave a talk, was presented.

Forever David will be remembered for his modesty and significant contribution as a role model in my life.

Asher Shainberg

$$
* * * * *
$$

\section{Developing and naming the rat myogenic line L6}

\section{by Sara Neuman, BSc}

Ness-Ziona, Israel. E-mail: saraneu@gmail.com

I was only 18 years old when I began to work in David's lab. I had just graduated from vocational school as a lab technician, with very little knowledge of biology, but with a strong desire to learn. For my first day in the lab, I was assigned to observe how two other technicians were establishing primary myogenic culture. When I understood the nature of the work that I was to do in the laboratory I thought that I would not return, but somehow, I did return the next day, and amazingly, continued to return for 40 years of interesting and rewarding research work.

We grew primary muscle cultures from newborn rats, giving them an acronym in Hebrew (Shuach for "Shrir Vlad Hulda"). David's goal was that we produce a cell line from muscle cells such that the cells would continue to divide, while preserving their ability to differentiate until we would induce them to do so. He felt that this would be more advantageous than using primary cultures to study myogenesis in particular, and cell differentiation in general, and would serve as a model system to answer basic questions of cell differentiation.

To achieve this goal, it was necessary to do many serial passages from the initial primary myoblasts while not allowing the cells to differentiate. David believed that this approach would yield a cell line that could maintain the properties necessary to form myotubes. If this approach was successful, it would be possible to analyze numerous parameters without the need to prepare primary cultures for each experiment. I'm not sure that I really understood completely what the goal of the experiment was at the time, but the path to get there was clear.

The following year, June 5-10, 1967, the Six-Day War broke out and David was drafted into reserve duty to fight in the war. He spent several months in the Sinai desert. I was left to continue my work with the cells, and I understood that above all, it was necessary for me to continue to passage the cells continually, twice a week, changing the medium so that they would not differentiate and fuse into myotubes. I knew that if the cells were to fuse, they would stop dividing and that would be the end of the plan to generate a cell line.

At that time I lived in Holon, a city on the outskirts of
Tel-Aviv. Each day of the War, during air raid sirens, and in its aftermath, I traveled an hour and a half each way with a change of buses to get to the Weizmann Institute in Rehovot. I came faithfully every day, months passed, and David wrote letters from the front. When David returned after several months and saw the cells, he understood that we had a cell line, and that our hopes had been realized.

David presented the establishment of the cell line at an international conference and then named the cell line L6 since it was founded during the Six-Day War. ${ }^{19}$

May his memory be a blessing.

Sara Neuman

$$
* * * * *
$$

\section{My mentor David Yaffe}

\section{by Gania Kessler-Icekson, PhD}

Head (retired), Laboratory of Cellular and Molecular Cardiology, Felsenstein Medical Research Center, Rabin Medical Center, Petah-Tikva, and Sackler Faculty of Medicine, Tel-Aviv University, Tel-Aviv, Israel.

E-mail: icekson@tauex.tau.ac.il

It was Summer 1969 when Dr. David Yaffe interviewed me for his laboratory at the Department of Cell Biology, The Weizmann Institute of Science. I have just graduated and was looking for an interesting MSc project. David asked the usual questions, my background, education, interests, and before turning me to the next interviewer, Professor Michael Feldman the Head of Department, he handed me a pencil and a blank paper "Will you draw me a stork standing on one leg?". Michael Feldman was more demanding, as I had to prove my knowledge of the state-of-the-art emerging molecular biology. I was accepted.

We were two years after the Six-Day War and David was deeply concerned about the repair of massive muscle loss in the wounded. His idea was to achieve vast muscle regeneration by the provision of externally grown myoblasts, particularly the so-called 'normal' myoblast cell lines recently generated by him. We injected the cells into freeze-wounded muscles of graft-rejectionsuppressed rats and realized with great frustration that the injected cells developed into tumors. What a disappointment for David! The next step was to inject neonatal primary myoblasts grown in culture into wounded muscles of syngeneic rats. We obtained nice integration of radioactively-labeled neonatal myoblasts within the heavily injured muscles that were fully regenerated. Despite the promising results with normal myoblasts and the clear proof of concept, David's disappointment of the cell-lines was such that the project was abandoned and was never published, except in a conference lecture and a paragraph in a book chapter. I was a shy beginner and did not insist on continuing the 
project. For my $\mathrm{PhD}$ thesis, I studied the stability and translateability of polyadenylated RNA in differentiating myogenic L8 cells; part of the research was in collaboration with David's postdoc, Rob Singer. ${ }^{31,35}$ The two projects were pioneering in the field. From my training by David I carried wide knowledge of cell biology, the courage to take on challenges and the perception that every detail in your observation is of utmost importance; all helped me find my way in science. And yes, I will ever appreciate David, the nature-lover, for taking me to his lab despite my failure to draw correctly a stork standing on one leg.

May he rest in Peace.

Gania Kessler-Icekson

$$
* * * * *
$$

\section{Working with David: from cell culturing to friendship}

\section{Erica Meghid Krull, MSc}

Easton, Massachusetts, USA.

E-mail: erica.meghid@gmail.com

It was with sadness that I heard about David Yaffe's passing.

I started working in David's lab in 1970, right after college, preparing myogenic cell cultures. Sara Neuman taught me everything, including the cell culture protocol: pinning live newborn rats to a board, in order to collect the thigh muscle. Being unhappy with this procedure, I came up with what I thought was a smart improvement. I decapitated the animals before skinning their thighs, and continuing the procedure as instructed, only to have an irate David storm in the lab to accuse me of ruining the cells' viability.

The cultures grew nevertheless, and this more humane practice was eventually accepted as the lab standard, its stormy origin forgotten. David and I developed a good work relationship, especially considering our similarity in keeping a messy desk but being able to find any document at will.

Although I left lab work, got a Master's degree in nutrition and worked as a Public Health nutritionist for 30 years, I remember fondly my time in David's lab.

I visited David many times during our travels to Israel, and I regret not being able to do so anymore.

Erica Meghid Krull

\section{Reflections on David Yaffe}

\section{Bruce Paterson, PhD}

NIH Scientist Emeritus, National Institutes of Health, Bethesda, Maryland, USA.

E-mail: patersob@mail.nih.gov

$\mathbf{I}$ just heard that David has passed away. This is truly the passing of one of the most important scientists in the muscle field. He opened the door to the study of mammalian myogenesis, just as Steve Hauschka and Irwin Konigsberg did for the study of avian myogenesis in the same time period. I met David when I was a grad student in Richard Strohman's lab in Berkeley. David's early studies on cultured mammalian muscle were exciting and I wanted to take advantage of the system to study myogenesis. After I received my $\mathrm{PhD}$ I was a Muscular Dystrophy Foundation postdoctoral fellow in David's lab from 1972 to 1974 . The other postdoc in the lab was Rob Singer, who is now at Einstein and studies single RNA molecules from cradle to grave. The two grad students were Gania Kessler and Haviv Dym. We had the support of two wonderful lab associates, Ruth and Sara. We had the freedom to carryout any experiments that would put David's ideas to the test. This was a great environment in which to develop as experimentalists and we all thrived. I want to send my condolences to David's wife, Ruth, and his two sons, Uri and Itay, and his daughter Ofra. My contribution was to show that the mRNAs encoding the muscle proteins were only made after myoblast fusion, ${ }^{25}$ and were not stored as inactive transcripts in the myoblast, as previously suggested by Stewart Haywood. My work in David's lab opened the door for me to the international muscle biology community through the yearly international EMBO muscle meetings he started. This changed my life forever. I also got the chance to explore the wonderful natural beauty of Israel from the Negev, to the Sinai, to the Red Sea with plenty of input from David. He was a nature enthusiast of the first order and knew the history of the country from biblical times to the present. The saddest time for me was the period during the Yom Kippur War. Many young scientists from the Institute were lost during that period. After I left Israel I took an extended postdoctoral position at the University of Edinburgh with John Bishop studying the changes in the complexity of mRNAs during the myoblast to myotube transition. This lead to a permanent position as a staff scientist in the Laboratory of Biochemistry at NIH under Bob Goldberg and Maxine Singer. Basically my life changed completely and my career goals were set because of my interactions with David. We spent time together at meetings and we were even roommates at a Gordon conference.

I will miss these interactions and his presence at the muscle meetings. Warm regards to David's family.

Bruce Paterson 
Developing the mouse myogenic line $\mathrm{C} 2$ and beyond: 45 inspiring years with David Yaffe

\section{by Ora Saxel Fuchs, BSc}

Rehovot, Israel. E-mail: orasaxel@gmail.com

I started working with David Yaffe in 1973, straight after receiving my BSc, a young woman with limited life experience. I retired 45 years later, with extensive life and work experience. For 40 of those years, I worked directly with David and even during the last 5 years, when I was in a different lab, I continued to interact with David on various projects. Working with David, I learned not only how to perform at the bench, but also to manage research and to interact with people of different positions and titles. David's unique, non-compromising, engaging personality, inspired endless dedication and unlimited optimism.

When I arrived at the lab, the rat myogenic lines were already developed. Our goal was to generate a mouse myogenic cell line. Toward this goal, I prepared myogenic cultures from $\mathrm{C} 3 \mathrm{H}$ mice. After several passages I noticed an impressive clone with amazingly looking "beautiful cells" and further isolated this clone which was named $\mathrm{C} 2$ - "C" comes from the donor mouse strain $\mathrm{C} 3 \mathrm{H}$ and " 2 " reflects the approach (the initial cultures were established from the muscle 2 days following its injury). The article describing the development of this cell line was published in 1977 in Nature (D. Yaffe and O. Saxel). ${ }^{30}$

Following this publication, we received inquiries from many international scientists and the $\mathrm{C} 2$ cells were readily sent to numerous laboratories interested in using this cell line to carry out research on the regulation of myogenesis. Subsequently, the cells were deposited at ATCC (American Type Culture Collection) and have become easily accessible and available to all. The number of published papers with the $\mathrm{C} 2$ cells reflects their immense contribution to scientific research advancement.

I will forever cherish what I have learned from Professor David Yaffe and hope to always carry on his optimistic approach. May his memory be a blessing.

Ora Saxel Fuchs

$$
* * * * *
$$

\section{David Yaffe: a passion for science}

\section{by David Greenberg, PhD}

Senior Research Associate, Department of Biological Chemistry, The Alexander Silberman Institute of Life Sciences, The Hebrew University of Jerusalem, Jerusalem, Israel.

E-mail: david.greenberg1@mail.huji.ac.il

I first came to David Yaffe's lab as a MSc student in 1983. One of the striking things about David was how much he loved Biology and wanted to understand it. Although he was already a full Professor in his 50's he liked nothing more than to look at my muscle cell cultures under a microscope, check with me how the differentiation was going, or look for some clones in my cell culture plates. He also was never afraid of new challenges. At this time David and his collaborator Professor Uri Nudel were trying to work the molecular basis of muscle cell differentiation, cloning muscle specific promoters and analyzing promoters. David who spent much of his career before the structure of DNA was even known, took up the challenge willingly, talked about sequences and cloning and RNA expression as if it was second nature. ${ }^{54}$ One of the important papers at the time that they published looked at evolutionary conservation between Actin from chicken to human. ${ }^{55}$

I returned to the lab in 1992 as a postdoc and David was again taking up new challenges. Together with Uri they had become leaders in the field identifying short isoforms of dystrophin, that at the time had recently been identified as the gene which when mutated causes Duchenne muscular dystrophy. David's wide ranging intellect was willing to try to test the functional role of this short isoform (named Dp71 by David and Uri) in a transgenic mice model. ${ }^{72}$ Again what seemed like a long shot resulted in an important paper in Nature Genetics on Dp71 function. ${ }^{75}$

But aside for a keen scientific instinct and a willingness to pursue his experimental goals what left the strongest impression about David was the love of the science. He wasn't that interested in the fame or honor, what drove him was the love of nature and the need to try to understand how it worked

David Greenberg

$$
* * * * *
$$

\section{My memories of David Yaffe: the beauty of nature in microscopic and large scales}

\section{by Rachel Sarig, PhD}

Senior Staff-Scientist, Department of Molecular Cell Biology, Weizmann Institute of Science, Rehovot, Israel. E-mail: rachel.sarig@weizmann.ac.il

I had the honor of being one of the last graduate students of David Yaffe. I joined his lab on January 1995 to study the role of Dp71, a shorter product of the Dystrophin gene discovered in David's lab. For that, we generated $\mathrm{KO}$ mice, which were the first viable $\mathrm{KO}$ mice in Israel. ${ }^{78,83} \mathrm{I}$ cherish the period of my graduate studies in which I've learned how to 'think' biology. David taught me how to ask the right questions and to observe cells at large and myogenic cells specifically.

After my postdoc I returned to David's lab to start my tenure track as a staff-scientist at Weizmann Institute of Science. This was a great opportunity for me to continue working with David on our mutual interest of studying 
the biology of myogenic cells. During this period I've gained more knowledge understanding the biology of the muscle stem-cell population and their capacity to give rise to other cellular lineages. David was very much up to date in all cutting-edge technologies and didn't lose his endless curiosity and motivation to establish new collaborations and receiving funds to support his research. The period in David's lab has imprinted a mark on my scientific work up to this date, and opened the door for me to the research field of differentiation and dedifferentiation programs. ${ }^{87,92,93}$

Besides science, I also acquired from David the great passion of hiking and the love of 'simple' nature, cherishing blooming of flowers and birds singing. He'd shown us some unique hidden places throughout the country in which I travel up to now, and for me they will always be "David's spots".

Rachel Sarig

$$
* * * * *
$$

\section{David Yaffe: an important contributor to my early academic life}

\section{Orna Halevy, PhD}

Professor, The Hebrew University, Faculty of Agriculture, Rehovot, Israel.

E-mail: orna.halevy@mail.huji.ac.il

With a great sadness I have learned that David is not with us anymore.

My way crossed paths with David's in the early 1990's when I started my research in the field of myogenesis. He was kind and gave me the famous $\mathrm{C} 2$ cells (the parental $\mathrm{C} 2 \mathrm{C} 12$ cell line) and guided me how to work with them. These cells were my main tool along the years and I have never forgot to cite and knowledge David for this major contribution to the muscle field. In 1996, even though I was still kind of a "fresh woman" in the myogenesis community, David invited me to be part of the organizing committee of the Myogenesis EMBO meeting that was held in Ein Gedi. ${ }^{103}$ For me it was a great honor but also quite a challenge, but we were all very happy that this meeting was a big success.

David and I never had any mutual collaboration but from time to time we had met, he always showed interest in my research and also in my personal life. He always kept his "young" look and attitude.

For me, hearing that he's gone is unimaginable, he was eternal.

\section{Orna Halevy}

\section{Farewell to my dear friend David}

\section{by Eijiro Ozawa, MD, PhD}

Director General Emeritus, National Institute of Neuroscience, NCNP, Tokyo, Japan.

E-mail: ozawa@ncnp.go.jp

I was informed that my friend David Yaffe has passed away. It was particularly sad for me. He has been my good friend.

I was a researcher in myogenesis and muscular dystrophy from the viewpoint of protein biochemistry and muscle cell culture. Of course I know very well how much he contributed in the world of myogenesis and muscular dystrophy research. But I will not mention his works this time but just delightful time spent with him.

I had a chance to know his name in 1969, when I was working at the Department of Embryology, Carnegie Institute of Washington, in Baltimore MD. Since we first met at the Symposium held in Philadelphia in 1983, we became good friends with each other. Since then I invited him to meetings held in Japan several times, even one time he took his wife Ruth and stayed in the dormitory of my institute, and in another visit, he took his daughter. $\mathrm{He}$ also gave me chances to visit Israel three times, in June 1985, February 1996 and October 1998. In my first visit, he took me together with Ruth to Jerusalem, Jericho and Masada, driving his car. And I visited his home at a kibbutz. It was a very nice experience. I recollect wonderful memories with them. In my second visit, the meeting was held ashore Dead Sea that was a great success. After the meeting, he took all the participants to the ruin of Masada. This time I had studied the history of Israel more; I realized the fight of the ancient citizens who fought against Roman Empire. In my third visit, he invited me together with Jeff Chamberlain from the University of Washington, Seattle, to a meeting held in Jerusalem. So, I have a lot of good and delightful memories with him.

For these few decades, we made it a rule to exchange an Israeli calendar and a Japanese one each year. Last year, I sent it to him but no answer. Thus, I wondered whether he is not in good health considering his age. It is because I myself am of the similar generation. And yesterday, I heard the sad news. I felt very lonely.

I am sorry but it is difficult for me to express my severe grief, in English. I would like to express my sincere sympathy to Ruth.

Eijiro Ozawa 


\section{Memories of David: my mentor who became my friend}

\section{by Don J. Katcoff, PhD}

Associate Professor, The Mina \& Everard Goodman Faculty of Life Sciences, Bar-Ilan University, RamatGan, Israel. E-mail: don.katcoff@biu.ac.il

I recently learned that Professor David Yaffe of the Weizmann Institute of Science had passed away after a long and fruitful life. David was my PhD advisor 19761981. It is my honor to put in writing some of my memories from those years. When I joined the lab, David was already known for establishing myogenic cell lines that could be used as a model system to study myogenesis. The myoblasts were initially cultured from newborn rats or from chick embryos. David found appropriate conditions to induce myogenesis in primary cultures on a very strict and predictable timeline, and then managed to establish rat cell lines that behaved similarly. Those cell cultures were induced to differentiate by changing media that initiated cell fusion into myotubes accompanied by the synthesis of the muscle specific proteins. Furthermore, these proteins assembled properly and produced myotubes that would even contract on the dish. The ability to repeat experiments with these cell lines led to a long and productive career during the course of which David trained many students and postdocs. I was privileged to be among them. David was a cell biologist with remarkable biological intuition beyond his direct mechanistic knowledge of cellular processes. In the search for how the myogenic developmental system worked, he focused on aspects of gene expression that were novel at the time. For example, it was clear to him that a likely control point in the expression of the contractile proteins should be the controlled production of the RNA that encodes those proteins. He thus set out to measure that RNA using the only method at the time cell free translation of RNA extracted from differentiating cultures and running the resulting (radioactively labeled) proteins on SDS polyacrylamide gels. By manipulating the cultures and by treatment with actinomycin D that prevents mRNA transcription, we were able to show that it is likely that indeed, control of myogenesis is at the transcriptional level. One day in 1977 or so, David returned from a conference abroad and was all excited. He had learned that techniques were being developed to isolate specific sequences of DNA that could be used to directly identify and measure the level of particular mRNA species in the cell. It was just the beginning of the molecular biology revolution, and David immediately understood that the new technologies that were being developed could advance our research tremendously. I remember him standing in the doorway of our lab explaining to me what he had just learned. His excitement was contagious. In short order we decided that I would drop what I had been doing since I joined the lab and that I and others in the lab would attempt to learn and perform the new technologies so that we could apply

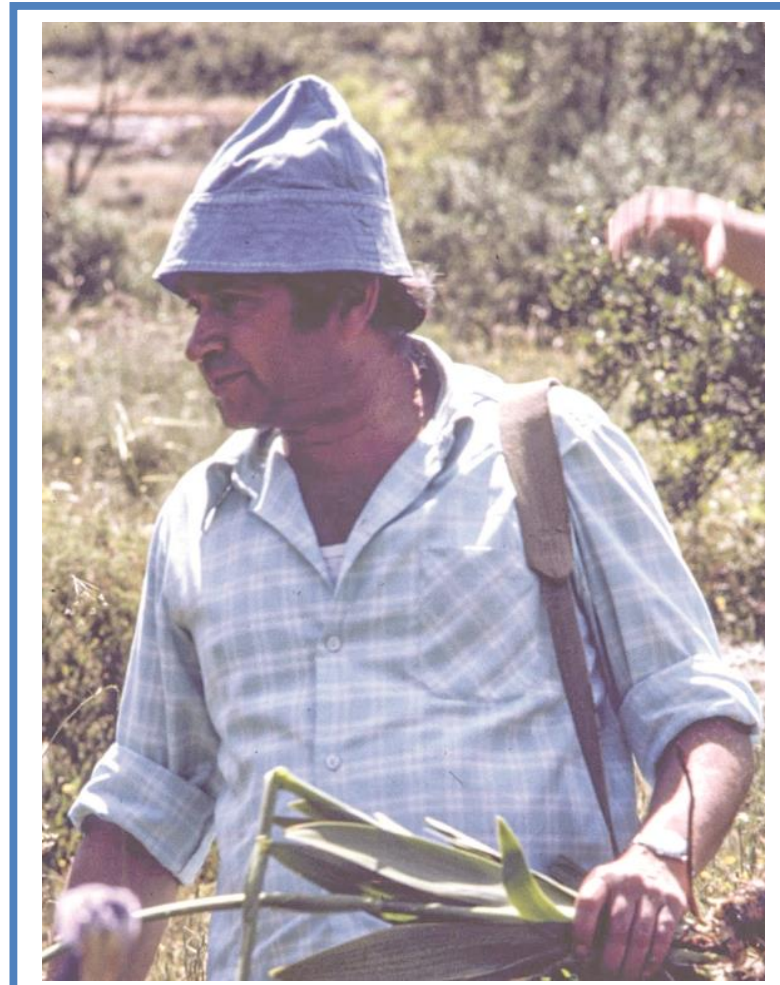

Fig 6. David was a lover of nature. Circa 1978. He periodically took his groups on trips in Israel. (Photo credit Dr. Don J. Katcoff).

them to the questions that we were studying.

Those were exciting times. David went on a sabbatical to Stanford from where he sent us protocols of techniques (like Northern blots) before they were published. We encountered many obstacles, but ultimately were able to clone cDNA's and the genes encoding alpha and beta actin, myosin light chains, myosin heavy chain, and tropomyosin. We used those cloned DNA segments to probe the RNA expression during myogenesis and published quickly. While there were competing groups abroad, we stayed ahead for the most part. David organized a conference in Israel that brought together most of the leading myogenesis research groups in the world. Our group starred at the conference, thanks to David's leadership.

On a personal level, David became a friend as well as an advisor. He was an Israeli to the core. He had lived through the birth of the State and participated in its wars. He loved the country and thus organized group outings from time to time. He was a member of a kibbutz (communal farming settlement) near the Weizmann Institute and as such participated in the communal responsibilities there. This involved kitchen duty in their dining room, guard duty and the like. On the one hand he was a professor and on the other a farmer.

Professor David Yaffe is sorely missed.

Don J. Katcoff

$$
* * * * *
$$




\section{Authors contributions}

Z.Y.-R. initiated, researched information, collected materials and contributions, and finalized the manuscript. Z.Y.-R., D.K. and D.G. translated (Hebrew to English) and/or edited some of the contributions. All coauthors discussed their contributions with the primary author during the preparation of this manuscript. All authors edited and approved the final manuscript.

\section{Acknowledgments}

The authors thank the A\&C Mioni-Carraro Foundation of Translational Myology for supporting this Ejtm Communication. Z.Y.-R. is grateful to Donna Goldberg, $\mathrm{MSc}$, for her insightful comments on the manuscript.

\section{Funding None}

\section{Conflict of Interest}

The authors declare they have no conflicts of interest.

\section{Ethical Publication Statement}

We confirm that we have read the Journal's position on issues involved in ethical publication and affirm that this report is consistent with those guidelines.

\section{Corresponding Author}

Zipora Yablonka-Reuveni, PhD, Professor, Biological Structure, University of Washington School of Medicine, Seattle, WA, 98115, USA

ORCID iD: 0000-0002-8855-263X

Email: reuveni@u.washington.edu

\section{Emails and ORCID iD of Coauthors}

Frank Stockdale: stockdale@stanford.edu Uri Nudel: uri.nudel@weizmann.ac.il

DavidIsraeli: Israeli@genethon.fr ORCID iD: 0000-0003-2762-2195

Helen M. Blau: hblau@stanford.edu ORCID iD: 0000-0001-6503-5480

Asher Shainberg: asher.shainberg@gmail.com ORCID iD: 0000-0001-5638-5788

Sara Neuman: saraneu@gmail.com ORCID iD: 0000-0002-0113-2334

Gania Kessler-Icekson: icekson@tauex.tau.ac.il ORCID iD: 0000-0003-3425-1396

Erica Meghid Krull: erica.meghid@gmail.com

Bruce Paterson: patersob@mail.nih.gov

Ora Saxel Fuchs: orasaxel@gmail.com

David Greenberg: david.greenberg1@mail.huji.ac.il ORCID iD: 0000-0001-8959-8640

Rachel Sarig: rachel.sarig@weizmann.ac.il ORCID iD: 0000-0002-4132-5114

Orna Halevy: orna.halevy@mail.huji.ac.il

ORCID iD: 0000-0002-8332-1736

Eijiro Ozawa: ozawa@ncnp.go.jp

Don J.Katcoff: don.katcoff@biu.ac.il

\section{References}

1. Feldman M, Yaffe D. Production of organ-specific antibodies following an induction of tolerance to antigens of heterologous organs. Nature 1957;179(4574):1353-4. doi: 10.1038/1791353a0.

2. Feldman M, Yaffe D. Immunogenetic studies on Xirradiated mice treated with homologous hematopoietic cells. J Natl Cancer Inst 1958;21:697-712.

3. Yaffe D, Feldman M. Immunogenetic changes induced in tumors grown in radiation chimeras. $\mathrm{J}$ Natl Cancer Inst 1959;23:133-51.

4. Feldman M, Yaffe D. Immunogenetic studies on Xirradiated mice treated with hematopoietic cells and grafted with tumor tissues. J Natl Cancer Inst 1959;23:109-31.

5. Yaffe D, Feldman M. Immunogenetic changes induced in tumors grown in radiation chimeras. $\mathbf{J}$ Natl Cancer Inst 1959;23:133-51.

6. Yaffe D. The distribution and in vitro propagation of an agent causing high plasma lactic dehydrogenase activity. Cancer Res 1962;22:57380.

7. Feldman M, Globerson A, Yaffe D. Immunological properties of chemically induced sarcomas. Acta Unio Int Contra Cancrum. 1963;19:65-72.

8. Yaffe D. Studies on an agent associated with high plasma lactic dehydrogenase activity. Acta Unio Int Contra Cancrum 1963;19:407-9.

9. Feldman M, Globerson A, Yaffe D. Immunological properties of chemically induced sarcomas. Philipp J Cancer 1963;5:562-73

10. Feldman M, Globerson A, Yaffe D. Body pains and loss of weight Cancer 1963;5:575-86.

11. Yaffe D, Feldman M. The effect of actinomycin D on heart and thigh muscle cells grown in vitro. Dev Biol 1964;9:347-66. doi: 10.1016/00121606(64)90030-2

12. Yaffe D, Feldman M. The formation of hybrid multinucleated muscle fibers from myoblastst of different genetic origin. Dev Biol 1965;11:300-17. doi: 10.1016/0012-1606(65)90062-X

13. Sadan N, Yaffe D, Rozenszajn L, Adar H, Soroker B, Efrati P. Cytochemical and genetic studies in four cases of Chediak-Higashi-Steinbrinck syndrome. Acta Haematol. 1965;34:20-9. doi: 10.1159/000209426

14. Rozenszajn L, Klajman A, Yaffe D, Efrati P. Jordans' anomaly in white blood cells. Report of case. Blood. 1966;28:258-65.

15. Feldman M, Yaffe D, Liron M, Bleiberg I. Regulatory mechanisms controlling the stability of cell differentiation. Cancer Res 1966;26:2041-4.

16. Yaffe D, Fuchs S. Autoradiographic study of the incorporation of uridine-3H during myogenesis in tissue culture. Dev Biol 1967;15:33-50. doi: 10.1016/0012-1606(67)90004-8

17. Yaffe D, Gershon D. The effect of polyoma virus 
on differentiating multinucleated muscle fibers. Isr J Med Sci. 1967;3:329-30.

18. Yaffe D, Gershon D. Multinucleated muscle fibres: induction of DNA synthesis and mitosis by polyoma virus infection. Nature 1967;215(5099):421-4. doi: 10.1038/215421a0

19. Yaffe D. Retention of differentiation potentialities during prolonged cultivation of myogenic cells. Proc Natl Acad Sci U S A 1968;61:477-83. doi: 10.1073/pnas.61.2.477

20. Yaffe D. Cellular aspects of muscle differentiation in vitro. Curr Top Dev Biol 1969;4:37-77. doi: 10.1016/s0070-2153(08)60480-9

21. Shainberg A, Yagil G, Yaffe D. Control of myogenesis in vitro by $\mathrm{Ca}^{2+}$ concentration in nutritional medium. Exp Cell Res 1969;58:163-7. doi: 10.1016/0014-4827(69)90127-x

22. Richler C, Yaffe D. The in vitro cultivation and differentiation capacities of myogenic cell lines. Dev Biol 1970;23:1-22. doi: 10.1016/s00121606(70)80004-5

23. Shainberg A, Yagil G, Yaffe D. Alterations of enzymatic activities during muscle differentiation in vitro. Dev Biol 1971;25:1-29. doi: 10.1016/00121606(71)90017-0

24. Yaffe D. Developmental changes preceding cell fusion during muscle differentiation in vitro. Exp Cell Res 1971;66:33-48. doi: 10.1016/s00144827(71)80008-3

25. Paterson BM, Roberts BE, Yaffe D. Determination of actin messenger RNA in cultures of differentiating embryonic chick skeletal muscle. Proc Natl Acad Sci U S A 1974;71:4467-71. doi: 10.1073/pnas.71.11.4467

26. Holtzer H, Jones KW, Yaffe D. Research group on neuromuscular diseases. A report on various aspects of myogenic cell culture with particular reference to studies on the muscular dystrophies. J Neurol Sci 1975;26:115-24. doi: 10.1016/0022-510x(75) 90120-3

27. Brunk CF, Yaffe D. The reversible inhibition of myoblast fusion by ethidium bromide (EB). Exp Cell Res 1976;99:310-8. doi: 10.1016/0014-4827 (76)90588-7

28. Yablonka Z, Yaffe D. Snythesis of polypeptides with the properties of myosin light chains direct by RNA extracted from muscle cultures. Proc Natl Acad Sci U S A 1976;73:4599-603. doi: 10.1073/pnas.73.12.4599

29. Yaffe D, Saxel O. A myogenic cell line with altered serum requirements for differentiation. Differentiation 1977;7:159-66. doi: 10.1111/j.1432 -0436.1977.tb01507.x

30. Yaffe D, Saxel O. Serial passaging and differentiation of myogenic cells isolated from dystrophic mouse muscle. Nature 1977;270(5639):725-7. doi: 10.1038/270725a0

31. Kessler-Icekson G, Yaffe D. Increased translatability in a cell-free system of RNA extracted from actinomycin D-treated cultures. Biochem Biophys Res Commun 1977;75:62-8. doi: 10.1016/0006-291x(77)91289-x

32. Yablonka Z, Yaffe D. Synthesis of myosin light chains and accumulation of translatable mRNA coding for light chain-like polypeptides in differentiating muscle cultures. Differentiation 1977;8:133-43. doi: 10.1111/j.1432-0436.1977.tb 00929.x

33. Dym H, Turner DC, Eppenberger HM, Yaffe D. Creatine kinase isoenzyme transition in actinomycin D-treated differentiating muscle cultures. Exp Cell Res 1978;113:15-21. doi: 10.1016/0014-4827(78)90082-4

34. Carmon Y, Neuman S, Yaffe D. Synthesis of tropomyosin in myogenic cultures and in RNAdirected cell-free systems: qualitative changes in the polypeptides. Cell 1978;14:393-401. doi: 10.1016/0092-8674(78)90124-1

35. Kessler-Icekson G, Singer RH, Yaffe D. The capacity of polyadenylated RNA from myogenic cells treated with actinomycin D to direct protein synthesis in a cell-free system. Eur J Biochem 1978;88:403-10. doi: 10.1111/j.1432-1033.1978.tb 12462.x

36. Atlas D, Yaffe D, Skutelsky E. Ultrastructural probing of beta-adrenoreceptors on cell surfaces. FEBS Lett 1978;95:173-6. doi: 10.1016/00145793(78)80077-5

37. Dym H, Yaffe D. Expression of creatine kinase isoenzymes in myogenic cell lines. Dev Biol 1979;68:592-9. doi: 10.1016/0012-1606(79)90229-x

38. Zevin-Sonkin D, Yaffe D. Accumulation of musclespecific RNA sequences during myogenesis. Dev Biol 1980;74:326-34. doi: 10.1016/0012-1606(80) 90434-0

39. Katcoff D, Nudel U, Zevin-Sonkin D, Carmon Y, Shani M, Lehrach H, Frischauf AM, Yaffe D. Construction of recombinant plasmids containing rat muscle actin and myosin light chain DNA sequences. Proc Natl Acad Sci U S A 1980;77:9604. doi: 10.1073/pnas.77.2.960

40. Nudel U, Katcoff D, Carmon Y, Zevin-Sonkin D, Levi Z, Shaul Y, Shani M, Yaffe D. Identification of recombinant phages containing sequences from different rat myosin heavy chain genes. Nucleic Acids Res 1980;8:2133-46. doi: 10.1093/nar/8.10. 2133

41. Shani M, Nudel U, Zevin-Sonkin D, Zakut R, Givol D, Katcoff D, Carmon Y, Reiter J, Frischauf AM, Yaffe D. Skeletal muscle actin mRNA. Characterization of the 3' untranslated region. Nucleic Acids Res 1981;9:579-89. doi: 10.1093 /nar/9.3.579

42. Shani M, Zevin-Sonkin D, Saxel O, Carmon Y, Katcoff D, Nudel U, Yaffe D. The correlation between the synthesis of skeletal muscle actin, 
myosin heavy chain, and myosin light chain and the accumulation of corresponding mRNA sequences during myogenesis. Dev Biol 1981;86:483-92. doi: 10.1016/0012-1606(81)90206-2

43. Yaffe D, Nudel U, Czosnek H, Zakut R, Carmon Y, Shani M. Analysis of myogenesis with recombinant DNA techniques. Adv Exp Med Biol 1982;158:127-37. doi: 10.1007/978-1-4899-52929_15

44. Czosnek H, Nudel U, Shani M, Barker PE, Pravtcheva DD, Ruddle FH, Yaffe D. The genes coding for the muscle contractile proteins, myosin heavy chain, myosin light chain 2 , and skeletal muscle actin are located on three different mouse chromosomes. EMBO J 1982;1:1299-305.

45. Nudel U, Katcoff D, Zakut R, Shani M, Carmon Y, Finer M, Czosnek H, Ginsburg I, Yaffe D. Isolation and characterization of rat skeletal muscle and cytoplasmic actin genes. Proc Natl Acad Sci U S A 1982;79:2763-7. doi: 10.1073/pnas.79.9.2763

46. Carmon Y, Czosnek H, Nudel U, Shani M, Yaffe D. DNAase I sensitivity of genes expressed during myogenesis. Nucleic Acids Res 1982;10:3085-98. doi: 10.1093/nar/10.10.3085

47. Zakut R, Shani M, Givol D, Neuman S, Yaffe D, Nudel U. Nucleotide sequence of the rat skeletal muscle actin gene. Nature 1982;298(5877):857-9. doi: 10.1038/298857a0

48. Czosnek H, Nudel U, Mayer Y, Barker PE, Pravtcheva DD, Ruddle FH, Yaffe D. The genes coding for the cardiac muscle actin, the skeletal muscle actin and the cytoplasmic beta-actin are located on three different mouse chromosomes. EMBO J 1983;2(11):1977-9.

49. Nudel U, Zakut R, Shani M, Neuman S, Levy Z, Yaffe D. The nucleotide sequence of the rat cytoplasmic beta-actin gene. Nucleic Acids Res 1983;11:1759-71. doi: 10.1093/nar/11.6.1759

50. Mayer Y, Czosnek H, Zeelon PE, Yaffe D, Nudel $\mathrm{U}$. Expression of the genes coding for the skeletal muscle and cardiac actions in the heart. Nucleic Acids Res 1984; 12:1087-100. doi: 10.1093/nar/12.2.1087

51. Melloul D, Aloni B, Calvo J, Yaffe D, Nudel U. Developmentally regulated expression of chimeric genes containing muscle actin DNA sequences in transfected myogenic cells. EMBO J 1984;3:983-90.

52. Shani M, Admon S, Yaffe D. The methylation state of 2 muscle-specific genes: restriction enzyme analysis did not detect a correlation with expression. Nucleic Acids Res 1984;12:7225-34. doi: 10.1093/nar/12.18.7225

53. Yaffe D, Nudel U, Czosnek H, Melloul D, Aloni B. The chromosomal assignment of muscle-specific genes. Adv Exp Med Biol 1985;182:295-307. doi: 10.1007/978-1-4684-4907-5_27

54. Nudel U, Greenberg D, Ordahl CP, Saxel O, Neuman S, Yaffe D. Developmentally regulated expression of a chicken muscle-specific gene in stably transfected rat myogenic cells. Proc Natl Acad Sci U S A 1985;82:3106-9. doi: 10.1073/pnas.82.10.3106

55. Yaffe D, Nudel U, Mayer Y, Neuman S. Highly conserved sequences in the 3' untranslated region of mRNAs coding for homologous proteins in distantly related species. Nucleic Acids Res 1985;13(10):3723-37. doi: 10.1093/nar/13.10. 3723

56. Yisraeli J, Adelstein RS, Melloul D, Nudel U, Yaffe D, Cedar H. Muscle-specific activation of a methylated chimeric actin gene. Cell 1986 Aug 1;46(3):409-16. doi: 10.1016/0092-8674(86) 90661-6

57. Einat P, Bergman Y, Yaffe D, Shani M. Expression in transgenic mice of two genes of different tissue specificity integrated into a single chromosomal site. Genes Dev 1987;1:1075-84. doi: 10.1101/gad.1.10.1075

58. Nudel U, Robzyk K, Yaffe D. Expression of the putative Duchenne muscular dystrophy gene in differentiated myogenic cell cultures and in the brain. Nature 1988;331(6157):635-8. doi: $10.1038 / 331635 \mathrm{a} 0$

59. Nudel U, Zuk D, Einat P, Zeelon E, Levy Z, Neuman S, Yaffe D. Duchenne muscular dystrophy gene product is not identical in muscle and brain. Natur. 1989;337(6202):76-8. doi: 10.1038/ $337076 \mathrm{a} 0$

60. Shinar D, Yoffe O, Shani M, Yaffe D. Regulated expression of muscle-specific genes introduced into mouse embryonal stem cells: inverse correlation with DNA methylation. Differentiation 1989;41:116-26. doi: 10.1111/j.1432-0436.1989. tb00739.x

61. Iujvidin S, Fuchs O, Nudel U, Yaffe D. SV40 immortalizes myogenic cells: DNA synthesis and mitosis in differentiating myotubes. Differentiation 1990;43:192-203. doi: 10.1111/j.1432-0436. 1990.tb00446.x

62. Einat P, Shani M, Yaffe D. The amount of the endogenous and exogenous skeletal muscle actin mRNA in the heart of transgenic mice is affected by the genotype of the cardiac actin gene. Differentiation 1990;44:36-41. doi: 10.1111/j. 1432-0436.1990.tb00534.x

63. Bar S, Barnea E, Levy Z, Neuman S, Yaffe D, Nudel U. A novel product of the Duchenne muscular dystrophy gene which greatly differs from the known isoforms in its structure and tissue distribution. Biochem J 1990;272:557-60. doi: 10.1042/bj2720557

64. Barnea E, Zuk D, Simantov R, Nudel U, Yaffe D. Specificity of expression of the muscle and brain dystrophin gene promoters in muscle and brain cells. Neuron 1990;5:881-8. doi: 10.1016/08966273(90)90348-j

65. den Dunnen JT, Casula L, Makover A, Bakker B, 
Yaffe D, Nudel U, van Ommen GJ. Mapping of dystrophin brain promoter: a deletion of this region is compatible with normal intellect. Neuromuscul Disord 1991;1(5):327-31. doi: 10.1016/09608966(91)90118-c

66. Makover A, Zuk D, Breakstone J, Yaffe D, Nudel $\mathrm{U}$. Brain-type and muscle-type promoters of the dystrophin gene differ greatly in structure. Neuromuscul Disord 1991;1:39-45. doi: 10.1016 /0960-8966(91)90041-p

67. Yaffe D, Makover A, Lederfein D, Rapaport D, Bar S, Barnea E, Nudel U. Multiple products of the Duchenne muscular dystrophy gene. Symp Soc Exp Biol 1992;46:179-88

68. Rapaport D, Passos-Bueno MR, Takata RI, Campiotto S, Eggers S, Vainzof M, Makover A, Nudel U, Yaffe D, Zatz M. A deletion including the brain promoter of the Duchenne muscular dystrophy gene is not associated with mental retardation. Neuromuscul Disord 1992;2:117-20. doi: 10.1016/0960-8966(92)90043-6

69. Rapaport D, Lederfein D, den Dunnen JT, Grootscholten PM, Van Ommen GJ, Fuchs O, Nudel U, Yaffe D. Characterization and cell type distribution of a novel, major transcript of the Duchenne muscular dystrophy gene. Differentiation 1992;49:187-93. doi: 10.1111/j.1432-0436.1992. tb00666.x

70. Lederfein D, Levy Z, Augier N, Mornet D, Morris G, Fuchs O, Yaffe D, Nudel U. A 71-kilodalton protein is a major product of the Duchenne muscular dystrophy gene in brain and other nonmuscle tissues. Proc Natl Acad Sci U S A 1992;89:5346-50. doi: 10.1073/pnas.89.12.5346

71. Rapaport D, Fuchs O, Nudel U, Yaffe D. Expression of the Duchenne muscular dystrophy gene products in embryonic stem cells and their differentiated derivatives. J Biol Chem 1992;267:21289-92.

72. Rapaport D, Greenberg DS, Tal M, Yaffe D, Nudel U. Dp71, the nonmuscle product of the Duchenne muscular dystrophy gene is associated with the cell membrane. FEBS Lett 1993;328:197-202. doi: 10.1016/0014-5793(93)80992-4

73. Lederfein D, Yaffe D, Nudel U. A housekeeping type promoter, located in the 3 ' region of the Duchenne muscular dystrophy gene, controls the expression of Dp71, a major product of the gene. Hum Mol Genet 1993;2:1883-8. doi: 10.1093/hmg/2.11.1883

74. Prigojin H, Brusel M, Fuchs O, Shomrat R, Legum C, Nudel U, Yaffe D. Detection of Duchenne muscular dystrophy gene products in amniotic fluid and chorionic villus sampling cells. FEBS Lett 1993;335:223-30. doi: 10.1016/0014-5793(93) 80734-c

75 Greenberg DS, Sunada Y, Campbell KP, Yaffe D, Nudel U. Exogenous Dp71 restores the levels of dystrophin associated proteins but does not alleviate muscle damage in $\mathrm{mdx}$ mice. Nat Genet 1994;8:340-4. doi: 10.1038/ng1294-340

76. Greenberg DS, Schatz Y, Levy Z, Pizzo P, Yaffe D, Nudel U. Reduced levels of dystrophin associated proteins in the brains of mice deficient for Dp71. Hum Mol Genet 1996;5:1299-303. doi: 10.1093/hmg/5.9.1299

77. Wang J, Pansky A, Venuti JM, Yaffe D, Nudel U. A sea urchin gene encoding dystrophin-related proteins. Hum Mol Genet 1998;7:581-8. doi: 10.1093/hmg/7.4.581

78. Sarig R, Mezger-Lallemand V, Gitelman I, Davis C, Fuchs O, Yaffe D, Nudel U. Targeted inactivation of Dp71, the major non-muscle product of the DMD gene: differential activity of the Dp71 promoter during development. Hum Mol Genet 1999;8:1-10. doi: $10.1093 / \mathrm{hmg} / 8.1 .1$

79. Vilquin JT, Guérette B, Puymirat J, Yaffe D, Tomé FM, Fardeau M, Fiszman M, Schwartz K, Tremblay JP. Myoblast transplantations lead to the expression of the laminin alpha 2 chain in normal and dystrophic (dy/dy) mouse muscles. Gene Ther 1999;6:792-800. doi: 10.1038/sj.gt.3300889

80. Keshet GI, Bar-Peled O, Yaffe D, Nudel U, Gabizon R. The cellular prion protein colocalizes with the dystroglycan complex in the brain. J Neurochem 2000;75:1889-97. doi: 10.1046/j.14714159.2000.0751889.x.

81. Neuman S, Kaban A, Volk T, Yaffe D, Nudel U. The dystrophin / utrophin homologues in Drosophila and in sea urchin. Gene 2001;263:1729. doi: 10.1016/s0378-1119(00)00584-9

82. Leibovitz S, Meshorer A, Fridman Y, Wieneke S, Jockusch H, Yaffe D, Nudel U. Exogenous Dp71 is a dominant negative competitor of dystrophin in skeletal muscle. Neuromuscul Disord 2002;12:83644. doi: 10.1016/s0960-8966(02) 00141-4

83. Dalloz C, Sarig R, Fort P, Yaffe D, Bordais A, Pannicke T, Grosche J, Mornet D, Reichenbach A, Sahel J, Nudel U, Rendon A. Targeted inactivation of dystrophin gene product Dp71: phenotypic impact in mouse retina. Hum Mol Gene 2003;12:1543-54. doi: 10.1093/hmg/ddg170

84. de León MB, Montañez C, Gómez P, MoralesLázaro SL, Tapia-Ramírez V, Valadez-Graham V, Recillas-Targa F, Yaffe D, Nudel U, Cisneros B. Dystrophin Dp71 expression is down-regulated during myogenesis: role of $\mathrm{Sp} 1$ and $\mathrm{Sp} 3$ on the Dp71 promoter activity. J Biol Chem 2005;280:5290-9. doi: 10.1074/jbc.M411571200

85. Neuman S, Kovalio M, Yaffe D, Nudel U. The Drosophila homologue of the dystrophin gene introns containing promoters are the major contributors to the large size of the gene. FEBS Lett 2005;579:5365-71. doi: 10.1016/j.febslet.2005.08. 073.

86. Bermúdez de León M, Montañez C, Gómez P, Luz 
Morales-Lázaro S, Tapia-Ramírez V, ValadezGraham V, Recillas-Targa F, Yaffe D, Nudel U, Cisneros B. Dystrophin Dp71 expression is downregulated during myogenesis: role of $\mathrm{Sp} 1$ and $\mathrm{Sp} 3$ on the Dp71 promoter activity. J Biol Chem 2005;280:5290-9. doi: 10.1074/jbc.M411571200

87. Sarig R, Baruchi Z, Fuchs O, Nudel U, Yaffe D. Regeneration and transdifferentiation potential of muscle-derived stem cells propagated as myospheres. Stem Cells 2006;24:1769-78. doi: 10.1634/stemcells.2005-0547

88. Shcherbata HR, Yatsenko AS, Patterson L, Sood VD, Nudel U, Yaffe D, Baker D, Ruohola-Baker H. Dissecting muscle and neuronal disorders in a Drosophila model of muscular dystrophy. EMBO J. 2007;26:481-93. doi: 10.1038/sj.emboj.7601503.

89. Taghli-Lamallem O, Akasaka T, Hogg G, Nudel U, Yaffe D, Chamberlain JS, Ocorr K, Bodmer R. Dystrophin deficiency in Drosophila reduces lifespan and causes a dilated cardiomyopathy phenotype. Aging Cell 2008;7:237-49. doi: 10.1111/j.1474-9726.2008.00367.x.

90. Fort PE, Sene A, Pannicke T, Roux MJ, Forster V, Mornet D, Nudel U, Yaffe D, Reichenbach A, Sahel JA, Rendon A. Kir4.1 and AQP4 associate with Dp71- and utrophin-DAPs complexes in specific and defined microdomains of Müller retinal glial cell membrane. Glia 2008;56:597-610. doi: 10.1002/glia.20633

91. Daoud F, Candelario-Martínez A, Billard JM, Avital A, Khelfaoui M, Rozenvald Y, Guegan M, Mornet D, Jaillard D, Nudel U, Chelly J, MartínezRojas D, Laroche S, Yaffe D, Vaillend C. Role of mental retardation-associated dystrophin-gene product Dp71 in excitatory synapse organization, synaptic plasticity and behavioral functions. PLoS One 2008;4:e6574. doi: 10.1371/journal.pone. 0006574

92. Aharoni R, Aizman E, Fuchs O, Arnon R, Yaffe D, Sarig R. Transplanted myogenic progenitor cells express neuronal markers in the CNS and ameliorate disease in experimental autoimmune encephalomyelitis. J Neuroimmunol 2009;215:7383. doi: 10.1016/j.jneuroim.2009.08.009.

93. Sarig R, Fuchs O, Tencer L, Panski A, Nudel U, Yaffe D. Cloned myogenic cells can transdifferentiate in vivo into neuron-like cells. PLoS One. 2010;5:e8814. doi: 10.1371/journal. pone.0008814.

94. Benabdesselam R, Sene A, Raison D, Benmessaoud-Mesbah O, Ayad G, Mornet D, Yaffe D, Rendon A, Hardin-Pouzet H, Dorbani-Mamine L. A deficit of brain dystrophin 71 impairs hypothalamic osmostat. J Neurosci Res 2010;88:324-34. doi: 10.1002/jnr.22198.

95. Dadon-Nachum M, Ben-Zur T, Srugo I, Shamir
HM, Melamed E, Yaffe D, Offen D. Therapeutic effect of myogenic cells modified to express neurotrophic factors in a rat model of sciatic nerve injury. J Stem Cells Regen Med 2012;8:21-7. doi: 10.46582/jsrm.0801004.

96. Dadon-Nachum M, Ben-Yaacov K, Ben-Zur T, Barhum Y, Yaffe D, Perlson E, Offen D. Transplanted modified muscle progenitor cells expressing a mixture of neurotrophic factors delay disease onset and enhance survival in the SOD1 mouse model of ALS. J Mol Neurosci 2015;55:78897. doi: 10.1007/s12031-014-0426-0.

97. Glat MJ, Benninger F, Barhum Y, Ben-Zur T, Kogan E, Steiner I, Yaffe D, Offen D. Ectopic muscle expression of Neurotrophic Factors improves recovery after nerve injury. J Mol Neurosci 2016;58:39-45. doi: 10.1007/s12031-0150648-9.

98. Guy R, Grynspan F, Ben-Zur T, Panski A, Lamdan R, Danon U, Yaffe D, Offen D. Human muscle progenitor cells overexpressing neurotrophic factors improve neuronal regeneration in a sciatic nerve injury mouse model. Front Neurosci 2019;13:151. doi: 10.3389/fnins.2019. 00151.

99. Some of the biographical information in this paragraph and the image in Fig 3 are from a PDF found online "The Graduates", published by the Weizmann Institute of Science, celebrating 50 years of excellence of its Feinberg Graduate School (published 2008).

https://wis-wander.weizmann.ac.il/books/graduates

Additional biographical details were contributed by Dr. Gania Kessler-Icekson.

100. Kern H, Boncompagni S, Rossini K, Mayr W, Fanò G, Zanin ME, Podhorska-Okolow M, Protasi F, Carraro U. Long-term denervation in humans causes degeneration of both contractile and excitation-contraction coupling apparatus, which is reversible by functional electrical stimulation (FES): a role for myofiber regeneration? J Neuropathol Exp Neurol 2004;63:919-31. doi: 10.1093/jnen/63.9.919

101. Kern H. Carraro U. Home-based functional electrical stimulation of human permanent denervated muscles: A narrative review on diagnostics, managements, results and byproducts Revisited 2020. Diagnostics 2020;10, 529. doi: 10. 3390/diagnostics10080529

102. EMBO workshop on muscle cell culture in the study of gene expression during differentiation, Shoresh, Israel, 1975.

103. EMBO workshop on myogenesis and molecular genesis of muscle diseases. Ein-Gedi, Israel, 1996.

Submitted: August 12, 2020 Accepted for publication: August 12, 2020 